\title{
NURSING DISCHARGE PLAN IN HOSPITALS: AN EXPERIENCE REPORT
}

\author{
Plano de alta de enfermagem no contexto hospitalar: um relato de \\ experiência
}

\begin{abstract}
Plan de alta de enfermería en los hospitales: un relato de experiencia
Jayanne Moreira Carneiro ${ }^{1}$, Larissa Oliveira de Jesus ${ }^{2}$, Caroline Santos Silva ${ }^{3}$, Ainara dos Santos Santiago Anderson Alves Lima Santos ${ }^{5}$ Patrícia Figueredo Marques ${ }^{6}$
\end{abstract}

How to cite this article:

Carneiro JM, Jesus LO, Silva CS, Santiago AS, Santos AAL, Marques PF. Nursing discharge plan in hospitals: an experience report. 2020 jan/dez; 12:1045-1049. DOI: http://dx.doi.org/0.9789/2175-5361.rpcfo.v12.7495.

\begin{abstract}
Objective: To describe the process of Alta Plans deployment in the Surgical Clinic of a large hospital in Salvador (BA). Method: Experience report describing aspects of the development, updating and implementation of five hospital plans nursing for surgical patients treated in this clinic. They were directed to the following surgical procedures: hernioplastias, cholecystectomy, hysterectomy, prostatectomy and amputation. Results: Five plans have been updated high, which were analyzed by the coordinating nurse, doctor and surgeon general supervisor of the mandatory component; after suggestions and changes made, it was referred to the Standards Commission that Hospital to be deployed in Surgery Units. Conclusion: The experience allowed the affirmation of instruments as an important educational materials for patients about post-surgical procedures and for nurses, that through this material can direct the necessary.

Descriptors: Surgery; Patient care planning; Patient discharge; nursing.
\end{abstract}

\section{RESUMO}

Objetivo: Descrever o processo de implantação de Planos de Alta na Clínica Cirúrgica de um hospital de grande porte de Salvador - Bahia. Método: Relato de experiência que descreve aspectos relacionados a elaboração, atualização e implantação de cinco planos de alta hospitalar de enfermagem para pacientes atendidos nessa clínica cirúrgica. Foram direcionados aos seguintes procedimentos cirúrgicos: hernioplastias, colecistectomia, histerectomia, amputação e prostatectomia. Resultados: Foram atualizados cinco planos de alta, os quais foram analisados pela coordenadora de enfermagem, médico cirurgião geral e supervisora do componente obrigatório; após sugestões e alterações realizadas, foram encaminhados para a Comissão de Padronização desse Hospital para serem implantados nas Unidades de Clínica Cirúrgica. Conclusão: A experiência possibilitou a afirmação dos instrumentos como um importante material didático para

1 Nursing Graduate by the Universidade Federal do Reconcavo da Bahia (UFRB), MSc in Collective Health by the Universidade Estadual de Feira de Santana (UEFS).

2 Nursing Graduate by the UFRB, MSc student in Collective Health by the UEFS.

3 Nursing Graduate by the UFRB, MSc in Collective Health by the UEFS.

4 Nursing Graduate by the UFRB.

5 Nursing Graduate by the UFRB.

6 Nursing Graduate, MSc in Nursing, PhD in Nursing by the Universidade Federal da Bahia (UFBA), Professor of the Nursing Department at UFRB. 
os pacientes sobre as condutas pós-cirúrgicas e para o enfermeiro, que através desse material consegue direcionar as orientações necessárias. Descritores: Cirurgia; Plano de cuidados de enfermagem; Alta hospitalar; Enfermagem.

\section{RESUMÉN}

Objetivo: Describir el proceso de implementación de los Planes de Alta en la clínica quirúrgica de un gran hospital en Salvador (BA). Método: Relato de experiencia que describe los aspectos del desarrollo, actualización y aplicación de los cinco planes hospitalarios de enfermería para pacientes quirúrgicos tratados en esta clínica. Ellos se dirigieron a los siguientes procedimientos quirúrgicos: hernioplastias, colecistectomía, histerectomía, la prostatectomía y amputación. Resultados: Cinco fueron actualizados a los planes de alto, que fueron analizadas por la coordinación de la enfermera, médico y cirujano supervisor general del componente obligatorio; después sugerencias y cambios realizados, se refirió a la Comisión de Normas que el Hospital que se desplegarán en las Unidades de Cirugía. Conclusión: La experiencia permitió a la afirmación de instrumentos como un importante material educativo para los pacientes sobre los procedimientos post-quirúrgicas y para las enfermeras, que a través de este material puede dirigir la orientación necesaria.

Descriptores: Cirugía; Planificación de atención al paciente; Alta del paciente; enfermería.

\section{INTRODUCTION}

The discharge process is a requirement of the Joint Commission on Accreditation of Healthcare Organization (JCAHO). ${ }^{1}$ The Discharge Plan (DP) is an interdisciplinary activity that has the nurse responsible for linking professionals aiming at the well-being and resources necessary to ensure the safety of home care.

The DP must be under development from the moment of the patient's admission, by strengthening the trust bond with the health professional. The possibility of effectively clarifying eventual doubts during the entire hospitalization guarantee assistance in its fullness. ${ }^{2}$

The individual affected by any type of disease is very vulnerable both in its physical and psychic aspects and even more so when the treatment chosen for his pathology is as invasive and traumatic as a surgery. ${ }^{3}$ Knowledge deficit ${ }^{4}$ - a nursing diagnosis that is often undervalued and solved regarding the surgical procedure, nutritional intake, the necessary change in the postoperative process, has its priority among the various aspects that surround it daily (religion, work, habit, environment). So, it is necessary to solve the specific and individual doubts of each one, considering that they are subjects who live in different environments. Hence, sensitive listening and resolving actions contribute to systematized care from admission to hospital discharge.

Nursing Care Systematization (NCS) as an organizational process can offer subsidies for the development of interdisciplinary and humanized methods of care. Therefore, it is the organization of work, according to the phases of its flow. ${ }^{5}$

The planning of nursing care guarantees the responsibility to the assisted client, since this process allows us to diagnose the client's needs, provide the proper prescription, in addition to being applied to health care. ${ }^{6}$ In clinical practice, it is observed that the guidance addressing hospital discharge is given when the patient leaves it. On that occasion, many orientations are offered simultaneously, the majority through verbal communication, making it difficult to understand. When considering the patient education, both verbal and written information are important and complementary. There is also the possibility that the patient does not understand verbal information, forget or reject it. ${ }^{7}$

To meet the patient's real needs, it is essential to observe the way he is welcomed and assisted by the nursing team, as they are factors that significantly influence the recovery and rehabilitation process. To be successful in their interventions, nursing needs to meet the biological, social, psychological, and spiritual demands of the patient, providing a holistic view from their embracement at the unit until their discharge. ${ }^{8}$

The discharge plan requires the dedication of a multidisciplinary team, with the interaction taking place between all professionals involved in the health-disease process and to minimize the fragmentation of care. Therefore, solutions can be provided based on the reality of the patients at the time of discharge, which is the most expected by them and their families. This moment is also marked by fear, insecurity, doubt, stress, and dependence on the care of health professionals. ${ }^{9}$

Bearing the aforesaid in mind, this work meant to describe the process of implementing Discharge Plans in the Surgery Units from a large hospital in Salvador city, Bahia State, Brazil.

\section{METHODS}

It is an experience report that describes aspects related to the experience of the graduates as nursing interns of the mandatory supervised internship component II of the Universidade Federal do Recôncavo da Bahia (UFRB), for their contribution in the elaboration, updating and implementation of the discharge plan nursing hospital for patients assisted at the Surgery Unit in a public hospital from the Bahia State.

The need for a script of nursing guidelines for patient discharge was perceived in the initial stages of the internship, in which there was great concern on the part of users concerning the ideal behavior for the continuity of care at home without risk of acquiring infections and consequent re-approach.

The surgeries and procedures that had the individualized care plan were chosen based on the epidemiological survey carried out in the diagnostic phase of the supervised internship. At the time, the nursing census was used as a database, in which it was sought to know the reasons related to hospital admission authorization from September 2014 to January 2015, with the five most prevalent being chosen, namely: Hysterectomy (54), Amputation (24), Hernioplasty (195), Prostatectomy (24) and Cholecystectomy (301), totaling 598 procedures. 
To meet the needs of the population assisted at the unit, a document was created with general hygiene and comfort guidelines, together with nutritional guidelines instituted by the sector's nutritionist, followed by specific guidelines for each type of surgery performed and a table scheduling medications in the patient's prescription at the time of hospital discharge. Thus, an illustrative material was obtained with clear and accessible language to ensure the understanding of users regardless of social level and educational level.

\section{RESULTS AND DISCUSSION}

Hospital discharge must be planned, organized, and systematized, in order to avoid possible readmissions due to the lack of understanding by the patient and/or family member of the information vis-à-vis the continuity of care. ${ }^{8}$

Given this standpoint, in order that the instructions concerning the care to be performed after hospital discharge are implemented effectively, five discharge plans were developed and updated, which constitute a document in which the actions to be developed are systematized. by patients for their rehabilitation, recovery, and health promotion.

Similar experiences were found in the literature review $\mathrm{w}^{9-19}$ and reinforced the importance and convenience in developing and updating these discharge plans instruments and corroborating their effectiveness and positive repercussion in the recovery of the health of individuals, who reiterate the protagonist position of these subjects in caring for their health.

Hospital discharge planning is considered to be an interdisciplinary responsibility process. Nevertheless, the nurse has a fundamental role in identifying the patient's needs, in educating family members and, therefore, in coordinating discharge planning. This professional must assess the patient's skills for self-care, as well as the family's interests and conditions in helping him, since the discharge plan aims to make the patient independent for performing his home care and/or provide adequate preparation for the family to undertake such care. ${ }^{15}$

In light of the literature and the Nursing Discharge Plans prepared by a group of interns in previous semesters, these Plans were updated in order to the implant (after approval by the responsible Team - Standards Joint Commission) in the Inpatient Surgery Unit from a large hospital in Salvador city, Bahia State.

The Plans are divided into three parts, as follows: general guidelines and conceptual description of the surgical procedure, specific guidelines, and a chart listing the medication to be taken.

The first part consists of the general care guidelines, as shown in Figure 1, which deals with personal hygiene, encouraging the disuse of alcoholic beverages and other legal and illegal drugs, control of risk factors for the development of chronic diseases, concerning the Diabetes Mellitus, Systemic Arterial Hypertension, Hypercholesterolemia, through nutritional guidelines regarding the use of some condiments and forms of food preparation, encouraging the disuse of industrialized products, replacing them with natural products, as well as the reduction and/or elimination of fried food from the diet.

Figure 1 - General care guidelines.

\begin{tabular}{c|} 
Nursing guidelines for patients undergoing \\
cholecystectomy
\end{tabular}

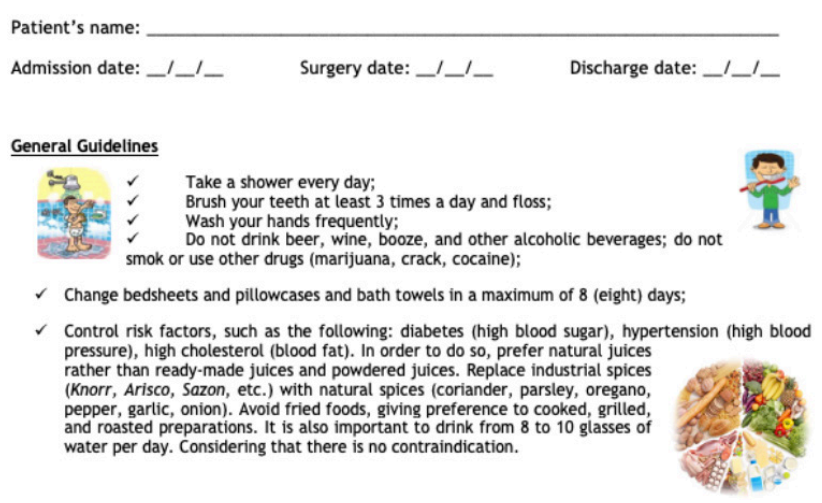

Currently, it is well known that chronic metabolic diseases are the ones that most affect people's health, which are predisposing factors for the onset and complications of other morbidities and that subject these individuals to undergo surgical procedures for their treatment.

Following, there is a brief conceptual description of the referred surgical procedures and specific care guidelines (Figure 2) for each performed intervention. Care practices are listed addressing the common signs and symptoms that arise after surgery, such as nausea and vomiting; as to the integrity and dressing of the surgical incision, highlighting aspects that patients can identify signs of inflammation and infection, such as hyperemia, edema, pain, hyperthermia, drainage of secretion, foul smell; furthermore, addressing the restricted period for weight lifting and sexual intercourse; also regarding healthy eating, body exercises, in cases of amputation, targeting to provide rehabilitation and health promotion.

Figure 2 - Surgical procedure and its specific care.

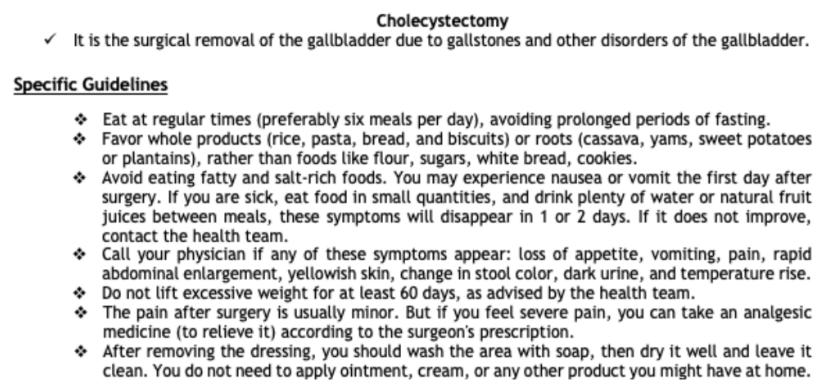
or plantains), rather than foods like flour, sugars, white bread, cookies.
Avoid eating fatty and salt-rich foods. You may experience nausea or vomit the first day after Avoid eating fatty and salt-rich foods. You may experience nausea or vomit the first day after
surgery. If you are sick, eat food in small quantities, and drink plenty of water or natural fruit surgery. If you are sick, eat food in small quantities, and drink plenty of water or natural fruit
juices between meals, these symptoms will disappear in 1 or 2 days. If it does not improve, Call your physician if any of these symptoms appear: loss of appetite, vomiting, pain, rapid
abdominal enlargement, yellowish skin, change in stool color, dark urine, and temperature rise. Do not lift excessive weight for at least 60 days, as advised by the health team.

* The pain after surgery is usually minor. But if you feel severe pain, you can take an analgesic

medicine (to relieve it) according to the surgeon's prescription.
- After removing the dressing, you should wash the area with soap, then dry it well and leave it

After removing the dressing, you should wash the area with soap, then dry it well and leave it
clean. You do not need to apply ointment, cream, or any other product you might have at home.

After these specific guidelines, there is a chart showing the medications to be taken (Figure 3), which guides users concerning the medications, time, and doses that they should use according to medical prescription. This instrument was used to support people's understanding towards the therapeutic regimen since most inpatients are either illiterate or have a low level of education. 
Figure 3 - Chart of medications.

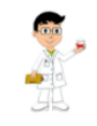

* Take your medications at the right time!

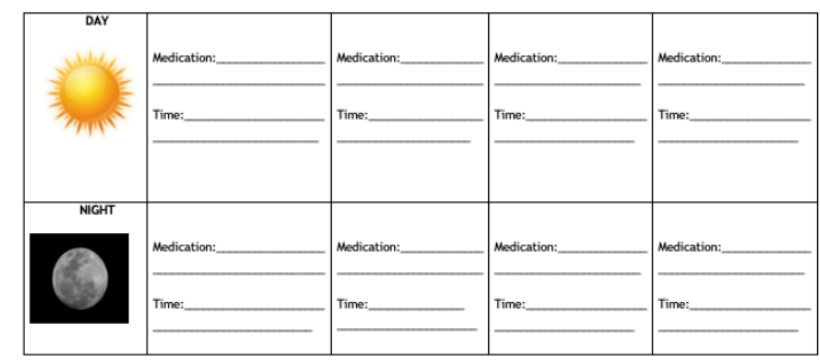

Notes:

\section{Registered Nurse}

During the process of preparing these Plans, some difficulties were confronted and were overcome due to the efforts of each participating member. Initially, developing the skill of summarizing content, as it was necessary to compile and summarize the information found in the literature in order not to produce extensive forms, which happened in the initial stages, and students were asked to review the plans and their summaries.

Moreover, the need to adapt the language to facilitate patients' understanding. The patient's ability to understand discharge instructions must be identified and considered at the time of hospital discharge so that this information is understood..$^{14}$ Hence the importance of students to record information clearly, simply and objectively; it has been eventually achieved.

Nonetheless, it should also be noted the easy steps for the elaboration of these instruments, which were due to the easygoing access of the students to the nursing team coordinator, to the internship supervisor, and the commitment of the members involved, as well as the acceptance of the Hospital professionals of this idea.

It is understood that the nursing professional, responsible for caring for the person in its physical, psychological and social aspects, plays a fundamental role in educating the patient concerning rehabilitation, recovery and health promotion; the nursing professional consists of an educator for providing care, and these Discharge Plans come to systematize these actions so that the individual can use his autonomy, as well as it places him as a protagonist of his own health care.

It is restated that these Plans provide subsidies for conscious decision-making, scientifically based to obtaining an effective result, then preventing the return of this individual to the hospital due to complications and/or after-effects from the undertaken surgical procedure. Accordingly, it complements the theoretical framework of the nursing profession, corroborating its scientific approach in addition to reinforcing the importance of this professional in the multiprofessional health team, acting in an interdisciplinary manner when assisting human beings.

Conclusively, after elaboration and appreciation by the responsible members of the Surgery Units, those forms were referred to the Standards Joint Commission of the Hospital, so that they could be assessed and adjusted to institutional standards, and later, implemented in such Units.

\section{CONCLUSION}

The experience gained from the elaboration, updating, and implementation of nursing discharge plans for patients undergoing surgical procedures, has placed the instruments as significant educational material.

Given this framework, the guidelines provided tend to enable patients to understand the appropriate post-surgical procedures for self-care and enable nurses to position themselves clearly and objectively, transmitting greater safety to the assisted population.

Hence, the contribution provided to the sector during the process of implementing the nursing care systematization and the five programs was considered of great value, which aims at enhancing the institution quality through organization and discipline in the workplace.

Therefore, the implementation of the hospital discharge plan in nursing work shares the objectives of the quality program, mainly concerning reducing costs with rehospitalization for failures in care after hospitalization, developing teamwork, improving the quality of relationships, and consequently, of the services provided by the institution.

Succinctly, it is believed that it is necessary to provide in didactic materials addressing the nursing daily practice, using illustrative resources and conventional writing. Based on such approach, the professionals will have more confidence when performing their actions since they will understand that the communication and the instruments have easily-assimilated information, adequate to solving patients' insecurity during the recovery process in the extra-hospital setting.

\section{REFERENCES}

1. Joint Commission on Accreditation of Healthcare Organization (JCAHO). Comprehensive accreditation manual for hospitals: the official handbook. Oakbrook Terrace: Joint Commission; 2005. Available at: http://www.mitsstools.org/uploads/3/7/7/6/3776466/ psc_for_web.pdf acessado em 25/05/2017.

2. Rigon, E et al. Plano de alta como estratégia para comunicação efetiva na internação hospitalar. Brazilian Journal of Surgery and Clinical Research - BJSCR. Vol.7,n.1,pp.30-34 (Jun-Ago 2014). Available at: http://www.mastereditora.com.br/periodico/20140602_103331.pdf acessado em 24/05/2017.

3. Madeira, MZA et al. A expectativa do paciente no pré e pós-operatório de prostatectomia. Revista Interdisciplinar NOVAFAPI, Teresina. v.3, n.1, p.13-18, Jan-Fev-Mar. 2010. Available at: http://uninovafapi. edu.br/sistemas/revistainterdisciplinar/v3n1/pesquisa/p1-v3n1.pdf acessado em 18/09/2016.

4. Tannure, MC; Pinheiro, AM. SAE: sistematização da assistência de enfermagem: gua prático/ SAE: systematization of nursing care: practical. Rio de Janeiro; Guanabara Koogan; 2011. 298. 
5. Santos, WN. Sistematização da assistência de enfermagem: o contexto histórico, o processo e obstáculos da implantação; J Manag Prim Health Care 2014; 5(2):153-158. Available at: https://grupos.moodle. ufsc.br/mod/resource/view.php?id=11823 acessado em 17/05/2017.

6. Silva, EGC; Oliveira, VC; Neves, GBC; Guimarães, TMR. O conhecimento do enfermeiro sobre a Sistematização da Assistência de Enfermagem: da teoria à prática. Rev Esc Enferm USP 2011;45(6):1380-6.

7. Coriolano-Marinus, MWL et al. Validação de material educativo para alta hospitalar de pacientes com prescrição de oxigenoterapia domiciliar prolongada. Esc Anna Nery 2014;18(2):284-289. Available at: http://www.scielo.br/pdf/ean/v18n2/1414-8145-ean-18-02-0284. pdf acessado em 25/05/2017

8. Bastos, AQ; Souza, RA; Souza, FM; Marques, PF. Reflexões sobre cuidados de enfermagem no pré e pós-operatório: uma revisão integrativa da literatura. Cienc Cuid Saude $2013 \mathrm{Abr} / J u n ; 12$ (2):382-390. Available at: www.periodicos.uem.br/ojs/index.php/CiencCuidSaude/ article/download/15724/pdf acessado em 18/08/2016

9. Jesus, DF; Marques, PF. Assistência de enfermagem na alta hospitalar após cirurgia cardíaca: revisão integrativa. Rev Bras Cir Cardiovasc vol.28 no.4 São José do Rio Preto outubro / Dec. 2013. Available at: http://www.scielo.br/scielo.php?script=sci_ arttext\&pid=S0102-76382013000400020 acessado em 25/05/2017

10. Blanck, M; Giannini, T. Úlcera e feridas, as feridas têm alma. Uma abordagem interdisciplinar do plano de cuidados e da reconstrução estética. Rio de Janeiro: Di Livros, 2014.

11. Cieto, BB; Garbuio, DC; Camargo, VB de; Napoleão, AA. Recursos e inovações de enfermagem para a alta: revisão integrativa. Revista Mineira de Enfermagem. 2014. ISSN: 2316-9389. Available at: http:// www.reme.org.br/artigo/detalhes/960 acessado em 18 de maio de 2015.

12. Inácio, LA; Montezeli, JH; Sade, PMC; Caveião, C; Hey, AP. Atuação do enfermeiro nas orientações de alta ao paciente pós-transplante renal. Rev. Enferm UFSM 2014 Abr/Jun;4(2):323-331. Available at: http://cascavel.ufsm.br/revistas/ojs-2.2.2/index.php/reufsm/article/ view/10186/pdf acessado em 18 de maio de 2015.

13. Ruiz, LD; Laurino, PS; Roma, M. Implantação do plano educacional no prontuário eletrônico para pacientes e familiares. Journal of health informatics - JHI. 2012. Available at: http://www.jhi sbis.saude.ws/ojsjhi/index.php/jhi-sbis/article/view/246/135 acessado em 18 de maio de 2015.

14. Teixeira, JPD de S. Educação do paciente sobre regime terapêutico medicamentoso no processo de alta hospitalar: uma revisão integrativa; Rev. Gaúcha Enferm. vol.33 nº.2 Porto Alegre Jun 2012 Available at: http://www.scielo.br/pdf/rgenf/v33n2/26.pdf acessado em 25/05/2017.

15. Andrietta, MP; Moreira, RSL; Barros, ALBL. Plano de alta hospitalar a pacientes com insuficiência cardíaca congestiva. Revista LatinoAmericana de Enfermagem. 2011; 9(6): 1445-52. Available at: http:// www.scielo.br/pdf/rlae/v19n6/pt_23.pdf acessado em 25/05/2017.

16. Suzuki, VF; Carmona, EV; Lima, MHM. Planejamento da alta hospitalar do paciente diabético: construção de uma proposta. Rev Esc Enferm USP. 2011. 45(2):527-32. Available at: http://www.scielo.br/ $\mathrm{pdf} / \mathrm{reeusp} / \mathrm{v} 45 \mathrm{n} 2 / \mathrm{v} 45 \mathrm{n} 2 \mathrm{a} 31$ acessado em: 18 de maio de 2015.

17. Mata, LRF da; Napoleão, AA. Intervenções de enfermagem para alta do paciente prostatectomizado: revisão integrativa. Acta Paul Enferm 2010;23(4):574-9. Available at: http://www.scielo.br/pdf/ape/ v23n4/21.pdf acessado em 18 de maio de 2016.

18. Abrignani, MG; De Luca, G; Gabriele, M; Tourkmani, N. The Health Department of Sicily "Regional recommendations for hospital discharge and communication with patients after admission due to a cardiologic event" decree. Monaldi Arch Chest Dis; 82(2):93-104, 2014 Jun. Available at: http://bases. bireme.br/cgi-bin/wxislind.exe/iah/online/?IsisScript=iah/ iah.xis \&nextAction $=\operatorname{lnk} \&$ format $=$ standard.pft\&indexSearch $=$ EX\&exprSearch $=$ N04.452.859.564.725\&lang $=$ p\&base $=$ MEDLINE acessado em 19 de maio de 2016.

19. Kariyawasam, NC; Dayaratne, B; Turner, P. Challenges in predicting health needs and disease patterns - a case study on the implementation of an electronic hospital separation record in Sri Lanka. Stud Health Technol Inform; 192:1067, 2013. Available at: http://bases.bireme.br/cgi-bin/wxislind.exe/iah/ online/?IsisScript=iah/iah.xis\&nextAction=lnk\&format $=$ standard. pft \&indexSearch =EX\&exprSearch =N 04.452.859.564.725 \&lang=p\&base=MEDLINE acessado em 19 de maio de 2016.

Received in: 30/04/2018

Required revisions: 21/08/2018

Approved in: 13/12/2018

Published in: 17/08/2020

Corresponding author

Jayanne Moreira Carneiro

Address: Universidade Estadual de Feira de Santana Av. Transnordestina, s/n - Novo Horizonte Feira de Santana /BA, Brazil

Zip code: $44036-900$

Telephone number: +55 (75) 99189-5933

Disclosure: The authors claim to have no conflict of interest. 